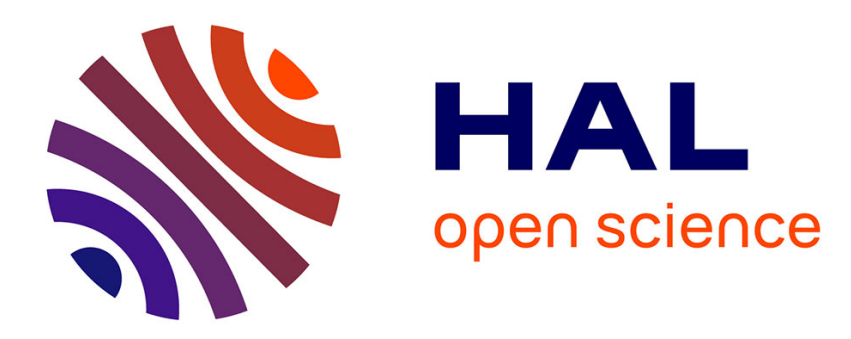

\title{
Comparing governments' efficiency at supplying income redistribution
}

\author{
Fabio Padovano, Francesco Scervini, Gilberto Turati
}

\section{To cite this version:}

Fabio Padovano, Francesco Scervini, Gilberto Turati. Comparing governments' efficiency at supplying income redistribution. Constitutional Political Economy, In press, 10.1007/s10602-020-09314-6 . hal02958623

\section{HAL Id: hal-02958623 \\ https://hal.science/hal-02958623}

Submitted on 9 Nov 2020

HAL is a multi-disciplinary open access archive for the deposit and dissemination of scientific research documents, whether they are published or not. The documents may come from teaching and research institutions in France or abroad, or from public or private research centers.
L'archive ouverte pluridisciplinaire HAL, est destinée au dépôt et à la diffusion de documents scientifiques de niveau recherche, publiés ou non, émanant des établissements d'enseignement et de recherche français ou étrangers, des laboratoires publics ou privés. 


\title{
Comparing governments' efficiency at supplying income redistribution ${ }^{1}$
}

\author{
Fabio Padovano ${ }^{2}$ Francesco Scervini ${ }^{3} \quad$ Gilberto Turati ${ }^{4}$
}

\begin{abstract}
We examine whether and to what extent political institutions explain different performances in income redistribution across countries. After reviewing the available data sources, the measures of income redistribution and the traditional demand side explanations of redistribution, we focus our analysis on supply side factors, like political and economic institutions, rent seeking processes and the resources and instruments available for redistribution. We provide robust empirical evidence on the association between these different factors and the observed degree of redistribution. Our analysis supports the view that - for a given demand of redistribution - political and economic institutions contribute to explain differences across countries in the observed degree of redistribution.
\end{abstract}

JEL CLASSIFICATION: D78, I38, H53, H11

KEYWORDS: redistribution, ex ante and ex post Gini coefficients, political and economic institutions

${ }^{1}$ We wish to thank Massimo Bordignon, Isabelle Cadoret, Reiner Eichenberger, Vincenzo Galasso, Arye Hillman, Ilpo Kauppinen, Gry Østenstad, Alessandro Petretto, Assaf Razin, Jan-Egbert Sturm, Thierry Verdier, Stanley Winer and all participants to the workshop on 'The Political Economy of Redistribution', Condorcet Center for Political Economy, University of Rennes 1, April 2012, the 2012 Scientific Meeting of the SIEP, Pavia, the 2013 EPCS Meeting, Zurich, and the 2016 CESifo Venice Summer Institute as well as an anonymous referee for comments on preliminary drafts of this work. The usual disclaimers apply.

2 Univ Rennes, CNRS, CREM - UMR 6211, Condorcet Center for Political Economy, F-35000 Rennes, France; and DSP, Università Roma Tre, Roma Italy); corresponding author, ORCID: 0000-0003$4820-4531$

${ }^{3}$ University of Pavia (Italy), francesco.scervini@unipv.it, +39.0382.98.4419, ORCID: 0000-00016403-5876

${ }^{4}$ Università Cattolica del Sacro Cuore, Rome (Italy), ORCID: 0000-0002-2146-7887 


\section{Introduction}

This paper aims to empirically analyse the political and institutional factors that affect countries' relative efficiency at supplying income redistribution, for a given demand of it. Government failures have cast serious doubts on the ability of public authorities to improve inefficient market outcomes. This argument, however, has not been similarly exploited to evaluate the efficiency with which governments pursue more equitable distributions of resources (Feld and Schnellenbach, 2014). Despite the importance of this matter and a large literature mapping the evolution of income and earnings inequality, we still have a poor knowledge on the redistributive performance of governments around the world: How much do governments redistribute? How do they compare in terms of redistribution? How much do ex-ante (market) inequality differ from ex-post (after government intervention) inequality?

Recent empirical analyses suggest that differences across Western economies in terms of the redistributive performance are large and somewhat unexpected. For instance, among the nine Western democracies considered in their work (Belgium, France, Germany, Great Britain, Italy, the Netherlands, Norway, Sweden and the United States), Lefranc et al. (2008) show that Italy and the United States are the most unequal countries in terms of both outcomes and opportunities. The result is certainly striking given both the relative size of the welfare spending in the two countries and the differences in their tax systems. One would expect Italy to achieve a higher amount of redistribution than the United States, while in fact the opposite occurs. Similar considerations could be made about France and the United Kingdom, two countries with similar redistributive performances, but quite different welfare states in terms of size and structure (mainly universalistic the French one, more oriented toward means testing the British one). Other studies, based on different methodologies and definitions of inequalities, reach similar results (Gottschalk and Smeeding, 1997; Roemer et al., 2003). The question is: why?

Standard public choice explanations of coercive redistribution (Romer, 1975; Meltzer and Richard 1981, 1983) emphasize the role of demand side factors, in particular the median voter, generally predicting that the middle class plays a pivotal role in redistributive policies. Yet, recent empirical tests based on the Luxembourg Income Survey dataset fail to support this 'median voter hypothesis'. Milanovic (2000) 
and Scervini (2012) found not only that the net gains from redistribution for the middle class are negligible, but also that the link between income and redistribution is lower than for any other income class. Moreover, the amount of redistribution targeted to the middle class is lower in more asymmetric societies, a result in strong contrast with the logic of the median voter theorem.

If voters' preferences for redistribution (the demand side) do not explain the amount of resources that governments devote to the reduction of inequalities, logic commands to look at the role played by the supply of redistribution, including the country-specific institutional frameworks where redistributive policies are decided and implemented.

This is the issue we address in this paper. To this end, we first systematically review the difficulties in measuring redistribution across countries. We then provide an empirical analysis of the relationship between the available measures of redistribution and the different supply side and institutional factors characterizing the countries for which data are available. Though we are not able to establish any strong causal links, our findings clearly suggest that political and economic institutions are important to explain how governments perform in terms of redistribution.

The remainder of the paper is organized as follows. Section 2 highlights the problems in measuring redistribution, discussing both conceptual issues and issues related to data availability. Section 3 reviews the empirical literature on the demand and supply of income redistribution. In section 44 we discuss the empirical strategy and the estimates. Section 5 concludes.

\section{The first step: measuring redistribution}

\subsection{Conceptual problems in measuring redistribution}

There is a large number of studies about the dynamics of earnings and income inequality (e.g., Gottshalk and Smeeding, 1997; Salotti and Trecroci, 2018), and, more recently, about the polarization of top incomes, especially in Anglo-Saxon countries (e.g., Atkinson et al., 2011, Piketty and Saez, 2013). Yet, much less work can be found on income re-distribution. A quite straightforward explanation is that, despite the two concepts are clearly related, redistribution poses more serious problems of 
measurement than inequality. The usual measure of income re-distribution is the difference between income distribution before any government intervention (typically, the market income) and income distribution after the full set of government policies have been implemented. ${ }^{5}$ In the literature, the Gini coefficient is the most widely used measure of income distribution; yet, most of the available microdata allow the computation only of the ex post Gini on disposable income, while the ex ante Gini on market income needs to be estimated. ${ }^{6}$ This requires a profound knowledge of the tax and spending rules for each country in each year, which is typically limited to a subset of policies, such as cash transfers and income taxes. The limitation introduces a bias in the measure of redistribution, as there is evidence that other policy tools (e.g., in-kind transfers, consumption taxes) produce redistributive effects (e.g., Besley and Coate, 1991, Mahler and Jesuit, 2006; Sonedda and Turati, 2005). Hence, most studies of income redistribution typically focus on one country or on a limited group of countries, and - more importantly - on a specific policy or transfer program (e.g., Danziger et al., 1981, for an old review). This is largely unsatisfactory if one is interested in comparing the overall redistributive performance of governments across the world.

Danziger et al. (1981) underline another important limitation of the difference between ex ante and ex post Gini coefficients, namely the definition of the counterfactual: what would have been the distribution of ex ante income in the absence of any government transfers and taxes? An accurate definition of the ex ante income requires considering the full set of general equilibrium changes in relative prices and incomes in the hypothetical case where all governments' programs had been removed. Danziger et al. (1981) argue that in such a scenario pre-transfers income would have been more equally distributed, which makes the difference in Gini indices a likely upper bound estimate of the degree of redistribution. ${ }^{7}$ Milanovic (2010) criticizes this approach to the measurement of redistribution, arguing that existing welfare regimes (and their generosity) are the result of the evolution of political processes within each

${ }^{5}$ An alternative indicator is the relative difference between ex-ante and ex-post income inequality (instead of the absolute difference). However, the two measures are highly correlated (more than .95) and most of the results of the present analysis are qualitatively similar using either measures. We decide to present results using absolute redistribution since it allows including the ex-ante Gini coefficient among regressors.

6 Such estimations usually rely on micro-simulation models that generate individual market incomes, which are then used to compute inequality indices.

7 Under the hypothesis that the behavioral response to changes in welfare provision be approximately the same across individuals and countries. 
country. When people vote for a given regime, they take into account both the eligibility rules and the change in behaviours entailed by these rules. Hence, the difference in the ex-ante and ex-post Gini is a correct measure to look at when attempting at measuring redistribution.

\subsection{Data availability problems in measuring redistribution}

More problems for the measurement of redistribution emerge from the available sources of data. Applied researchers can rely on at least three sources, which differ significantly in terms of quality and cross-country comparability. Lisdatacenter (former Luxembourg Income Study, LIS) produces the most comprehensive crosscountry comparable data on income inequality and redistribution. Lisdatacenter collects country-specific household surveys from high- and middle-income countries and harmonizes these data to provide individual-specific information about income, labour market and socio-economic characteristics. The resulting microdata are highly comparable, but limited to a very small set of countries and years. In particular, Lisdatacenter provides a strongly unbalanced panel of less than 50 countries starting from 1967 up to 2013, for a total of about 250 data points, with most of the countries having fewer than 10 observations, not necessarily in consecutive years. Countries included are mainly OECD members, but the sample contains observations also from Georgia, Guatemala and Taiwan. In this paper we use Lisdatacenter micro-data to compute ex-ante and ex-post Gini coefficients and the mean/median ratio, according to the definition of income in Milanovic (2000). The information in Lisdatacenter allows us to generate a measure of household ex-ante factor income that includes labour pension transfers (excluding any other social transfer not related to market income contributions, such as invalidity and health-related transfers, and other subsidies) for all family members, and to compute total equivalent household income using the square root scale, which is independent of the age of household members. The same procedure is used to compute ex-post income: starting from the factor income, we sum all the household transfers and subtract all the taxes paid by household members, and we then compute the ex-post equivalent disposable income. Two reasons motivate our choice of considering equivalent incomes: on the one hand some tax-transfers schemes depend on household composition, and therefore it is important to take it into account when assessing the redistributive effects of taxation; on the other hand, equivalent 
income provides a better measure for individual well-being when dealing with household income.

A second source is SWIID, which relies on the WIID dataset (UNU-WIDER, 2015) and fills the missing information in WIID using multiple imputation techniques, validating it by using the higher-quality LIS data ${ }^{8}$. The SWIID database provides a fully comparable panel of country/year Gini coefficients on both market and net incomes. With respect to LIS, it has the great advantage of a much wider coverage: it is still an unbalanced panel, but includes 169 countries from 1960 to 2013, for a total of 4627 country/year cells. The drawbacks are that only the Gini coefficients on market and net incomes are available, and the fact that - since data are estimated - one needs to account for multiple imputations. ${ }^{9}$ All the analyses in this paper adopt appropriate empirical methodologies for analysing SWIID data.

Finally, the OECD Income Distribution Database (IDD) provides an unbalanced panel of comparable data on inequality in OECD countries. Differently from LIS, IDD does not provide microdata, but makes available several inequality measures (Gini coefficients on market, gross and net incomes, and five different decile ratios). The main drawbacks are that the country coverage is very limited (only 32 countries) and the panel is severely unbalanced. ${ }^{10}$ The time span ranges from 1976 to 2014 , for a total of 221 observations.

Given these sources, it is no surprise that the empirical literature on redistribution suffers from both the lack of comparable data and from their quality. Most of the papers rely on LIS data (Milanovic, 2000; Tanninen and Tuomala, 2001;

\footnotetext{
${ }^{8}$ Multiple imputation is an iterative form of stochastic imputation. However, instead of filling in a single value, it employs the distribution of the observed data to estimate multiple values, then reflecting the uncertainty around the "true value" (see Allison, 2002, for a detailed description of multiple imputation procedures). Therefore, SWIID dataset includes 100 values for each data point and this requires special treatment in the regression analysis. Solt (2016) provides details on the SWIID version 5.0 which we use in this paper, together with the estimation procedures employed to generate the imputed values. While WIID only collects data from very heterogeneous sources, classifying them according to quality, units of analysis, population coverage and so on,

${ }^{9}$ The statistical packages can handle this kind of data, essentially repeating each analysis 100 times and then averaging the results, taking also into account the variability around the mean. However, some advanced estimation techniques, such as the GMM, may not be dealt and therefore cannot be used with multiple imputed data.

10 Most observations relate to Canada and Finland, with 36 years and 27 years covered respectively; on the other hand, less than 5 observations are available for Chile, Japan, and Australia.
} 
Mahler and Jesuit, 2006; Scervini 2012; Feld and Schnellenbach, 2014), while only recently scholars have started looking at SWIID data (e.g., Sturm and De Haan, 2015).

Table 1 compares the ex-ante and the ex-post Gini coefficients on the small sample of country/year observations common to the three sources, while Figures 1-2 plot the pairwise comparisons. The Gini coefficients on net incomes (ex-post Gini) are very similar in the three datasets, while the Gini coefficients on market/gross incomes (ex-ante Gini) are much smaller for LIS. This is due to the fact that, in line with Milanovic (2000), the definition of gross income in LIS includes public pension transfers, on the ground that pensions are mostly 'deferred incomes', rather than redistribution. Consistently, market income inequality in the OECD and SWIID are virtually identical. In the light of $(i)$ the small differences between IDD and SWIID, (ii) the fact that the sample of countries in IDD is very similar to that in LIS and (iii) given the results of the regressions presented in Table 4 (see section 4.3 for more details), we exclude IDD from our analysis for the sake of parsimony, and focus only on LIS and SWIID data in order to account for the differences in the definition of income and in the sample of countries. Table A1 in the Appendix lists the SWIID countries used for our analysis and the subset of those included in LIS.

[Table 1 and figure 1-2 about here]

Table 2 shows the descriptive statistics for these two data sources. Notice that, because of the multiple imputation procedure, the mean values in SWIID need to be estimated and standard errors are presented instead of standard deviations for both Gini coefficients and absolute redistribution. Table 3 presents the variance decomposition of the Gini coefficients in the LIS sample. As expected, most of the variance of both inequality and redistribution is between countries, while the within country variation is relatively small. Unfortunately, it is impossible to decompose the variance of multiple imputed datasets, like SWIID.

[table 2 and 3 about here]

\section{The second step: identifying the supply side of redistribution}

As anticipated in the introduction, most of the empirical literature on the determinants of redistribution has focused on demand side factors. Alesina and 
Giuliano (2011) survey a number of variables that affect citizens' preferences for redistribution, including, for example, the perceived social mobility, religious beliefs and political ideology. Yet, these indicators are poor explanatory variables for the countries' aggregate demand of redistribution, as their time variation is often limited. Furthermore, the selection of the variables is largely data driven, since they must be available for the same country/year combinations for which the Gini differences are. For these reasons, the variables most often used as determinants of the voters' preferences for redistribution are: 1) measures of ex ante inequality (Tanninen and Tuomala, 2001; Scervini, 2012), usually found to be positively related with the demand for redistribution. ${ }^{11}$ 2) The dependency ratio (considering both the young and the elderly cohorts of the population), although this variable often turns out not statistically significant (Tanninen and Tuomala, 2001; Mahler and Jesuit, 2006). 3) The unemployment rate, which increases the demand for redistribution (Mahler and Jesuit, 2006). 4) Ethno-linguistic fractionalization, which should instead be negatively correlated with redistribution, since in more fractionalized countries people internalize less the positive externalities of redistribution. The findings in Sturm and De Haan (2015) suggest that such a result is conditional on the level of economic freedom: capitalist countries have a low degree of fractionalization and redistribute more. 5) Similar to measures of ethno-linguistic fractionalization, indicators of social capital, social cohesion and trust in government have been analysed as determinants of the demand of redistribution, for instance in order to explain the high levels of tax progressivity in Scandinavian countries. When conducted at the macro-level, crosscountry regressions yield results that are mixed at best, often because of the aforementioned data limitations (Alesina and Giuliano, 2011); when instead, individual level data are explored, results are often contradictory, because the samples examined refer to individual countries, and the quite specific nature of each analysis makes out-of-sample generalizations quite problematic ${ }^{12}$. 6) Finally, empirical tests of

11 This result is in contrast with De Mello and Tiongson (2003), who however focus on "redistributive transfers" to assess whether more unequal societies redistribute more. This difference suggests that transfers per se need not being redistributive and the whole array of redistributive devices available to governments must be considered when trying to assess redistribution.

${ }^{12}$ For instance, using Japanese data Yamamura (2012) finds that greater social interaction leads to preferences for more redistribution, especially in the upper end of the income distribution. Roth and Wohlfart (2018) instead look at individual level survey data from a variety of countries and find that, even controlling for social capital and a variety of individual level characteristics, people who had experienced greater inequality of incomes when young develop ideas of fairness such that they demand less redistribution when adults. 
median voter-based theories of the demand for redistribution are usually not supported by the data, as the middle class appears to obtain fiscal gains lower than those accruing to poorer individuals (Milanovic, 2000; Scervini, 2012).

Since the demand of redistribution only partly explains the variation of redistributive performances, it is important that research turns its attention to the supply of redistribution. "Supply side" explanatory variables of redistribution are basically of two types: first, the political and the economic institutions that condition the redistributive choices (like the type of political regime and the voting mechanism); second, the instruments and the resources available for redistribution (the structure of the personal income tax, the composition of the public budget in terms of both revenue and spending, per capita income and GDP growth).

Among the political variables, it is important to distinguish a time frame in which political institutions can be considered as given, from one where the demand for redistribution may even modify these institutions. In the short run, for a given set of political institutions, the demand of redistribution can affect, for instance, the political orientation of the government, as well as its fragmentation. In a longer perspective, however, the demand for redistribution can have an impact also on the democratization process and on the choice between presidential versus parliamentary regimes, modifying political institutions to make them more effective at achieving a given redistributive goal (e.g., Boix, 2003; Acemoglu and Robinson, 2015; Aidt and Franck, 2015). In the context and sample period of our analysis, political institutions can be reasonably assumed to be exogenous (Persson and Tabellini, 2003).

Among the political and institutional variables that have shown some explanatory power in previous studies, there are dummies that identify presidential regimes, which appear to be negatively correlated with redistribution (e.g., Scervini, 2012). Mahler and Jesuit (2006) attribute a role also to voter turnout, recognizing welfare states and redistribution as the results of conflicts between class-related interest groups. In their empirical analysis, the higher is the turnout, the higher are social conflicts and the degree of redistribution. Feld and Schnellenbach (2014) consider how the decentralization of taxing and spending powers influences redistribution. They find a robust negative relation between tax autonomy and total redistribution, which however turns positive once fiscal equalization schemes are accounted for. They interpret this evidence as the result of the role played by 
federations in achieving redistribution via intergovernmental transfers; in this way for the first time they explicitly focus on political institutions as a fundamental determinant of the degree of redistribution achieved by one country. Finally, also economic institutions might shape the degree of redistribution. Mahler and Jesuit (2006) consider, for instance, the labour market institutions, such as the degree of 'corporatism' in institutional arrangements and the unionization rate. Regression analysis confirms that the degree of corporatism is statistically significant, and it increases redistribution.

\section{The third step: regression analysis}

\subsection{The empirical strategy}

Our goal is to analyze whether and how supply side factors play a role in determining the actual degree of redistribution in a country, controlling for the demand of redistribution. Following the literature, our dependent variable is the difference between the Gini ex ante and the Gini ex post in country $i$ in year $t$ $\left(G I N I_{-} D I F F_{i t}\right)$. We adopt an augmenting strategy, in that we consider three sets of explanatory variables. First, we estimate a baseline model where we examine only the impact of variables related to the demand for redistribution, which have received more attention in the literature so far (vector $X$ ). We then augment this baseline model taking into account political and economic institutions, the main supply side variables for redistribution (vector $W$ ); third, we examine the role played by the main instruments for redistribution, namely public spending, and then consider also the available resources for redistribution, including also public deficit and debt, and the composition of the public budget (vector $Z$ ). Equation [1] represents our general model:

GINI_DIFF $F_{i t}=\alpha+\sum_{j} \beta_{j} X_{j i t}+\sum_{k} \beta_{k} W_{k i t}+\sum_{h} \beta_{h} Z_{h i t}+\varepsilon_{i t}$

where $\varepsilon_{i t}$ is a stochastic disturbance. To account for the likely presence of heteroskedasticity and the correlation across periods of time in the disturbance, standard errors are clustered by country in all our estimates. We investigate the impact of clustering on our baseline estimates, by using also non-clustered standard errors, as well as the more traditional Panel Corrected Standard Errors proposed by Beck and Katz (1995). Notice that, starting from the discussion in Section 3 and consistently with the descriptive statistics in Table 3, country fixed effects are not included in the model, 
since most institutions change only in the long run; hence, identification must be based on cross-sectional variations in political institutions. We do include, however, macroregion fixed effects for Africa, Americas, Asia, Europe, Middle-East and Oceania in all models. As there are several reasons why the evolution of political and economic institutions might be similar for countries in the same macro-region, identification is difficult also in these models, because of the same low variability detected at the country level. Time fixed effects are included only when using SWIID data, i.e., when the sample size is sufficiently large and the panel structure is sufficiently long and complete. As for the sample size, we estimate the model considering different sources of data. We first use all the available observations for each source, and then we restrict the samples to match the year/country data available in the LIS sample, since it is the most limited, but also the one with the highest quality.

Finally, despite the efforts in properly modelling the error process, it must be stressed that causal inference is problematic for at least two issues. One is endogeneity and reverse causality, especially for the instruments and the resources for redistribution, which in the short run can be affected by the degree of inequality, and the consequent demand for redistribution. It is definitely less problematic for political and economic institutions, which can be affected by the degree of inequality only in the (very) long run. The second issue is parameter heterogeneity, a common problem for cross-country macro regressions (e.g., Temple, 1999). For instance, the way in which corruption affects redistribution may vary from one country to another, despite the inclusion of a number of controls in the model. For both reasons, we take a conservative approach and interpret the present analysis as a search for robust ceteris paribus correlations.

\subsection{Data and definitions for controls}

We have already discussed data and definitions for the dependent variable in section 2. In order to study the role of supply side variables on redistribution we now need to find the corresponding controls for all country/year for which a measure of redistribution is available. Again, this is not an easy task. Political data come from the PolityIV dataset (Marshall et al., 2016) and the World Bank Dataset on Political Institutions (DPI) (Beck et al, 2001, Cruz et al, 2015). In particular, from PolityIV we use the Polity 2 composite index of democracy, which ranges between -10 (least 
democratic) and +10 (most democratic countries), according to a wide set of institutional features, such as competitiveness and openness of executive recruitment, the constraints on the chief executive, the competitiveness of political participation and so on. From DPI we derive the political orientation of the government in office, the electoral system (proportional vs. majoritarian), or the institutional design (presidential vs. parliamentary). From the Fraser Institute (Gwartney et al., 2015) we take indicators of freedom from corruption, freedom from regulation (as well as its components freedom from labour market regulation, freedom from credit market regulation, freedom from business regulation), and the size of government, proxied by the top marginal tax rate index. It is worth noting that all these measures assume that regulation and freedom are always in contrast, so that less regulation, lower taxes, smaller government all lead to greater freedom. Finally, we use measures of public spending (total and by categories) and per capita GDP published by the World Bank World Development Indicators. Summary descriptive statistics for all the variables are reported in Table 2.

\subsection{Results}

\subsubsection{Baseline model: demand side indicators}

Table 4 shows our baseline analysis, which includes only demand side variables. In particular, we consider the ex-ante Gini coefficient on market income and the ratio between mean and median market income as proxies of the preferences for redistribution. According to the standard Meltzer and Richard (1981, 1983) argument, for both variables we expect a positive relationship with redistribution: the more unequal the distribution, the higher should be the demand for redistribution.

Results are consistent across the three sources (LIS, SWIID, OECD), both when using all the available data (full samples) and restricted samples featuring the country/year data available in the LIS. They remain consistent when different definitions for the standard errors are adopted, even though, as expected, clustering at the country level appears to be the most restrictive option. In particular, the coefficient on the Gini index provides support to the traditional Meltzer and Richard story: the more unequal the distribution, the higher the demand for redistribution. In line with Scervini (2012), however, the coefficient for the mean to median income ratio is 
consistently negative and significant. This result cannot be explained within the traditional Downsian approach, as it requires assuming, for instance, that richer individuals have more political power with respect to the other ones. Larcinese (2007) provides a straightforward explanation for this, arguing that richer individuals are more likely to vote. Hence, office-seeking candidates might target these individuals instead of the median voter when defining their platforms. Voter turnout becomes then relevant in explaining the observed degree of redistribution; what Larcinese (2007) does not take into account is the fact that different political institutions might also affect voter participation (on this point see the evidence provided by, e.g., Blais et al., 2003).

[table 4 about here]

The stability of results across full samples and restricted samples for all datasets helps in solving a further concern about the imputation procedure in SWIID, namely the possibility that the coefficient estimates are driven by the imputation itself, if the algorithm is somehow correlated to the regressors included in our models. ${ }^{13}$ Since the results are very similar, however, we are re-assured that the SWIID imputation procedure is not driving them. In addition, since the results are quite similar across samples and regardless of the different definitions for the standard errors, in the remainder of the analysis we cluster errors at the country level and compare LIS and SWIID data only.

In Table 5 we augment the baseline model by including the size of the public sector, measured by the ratio of public spending to GDP. According to the traditional Meltzer and Richard approach, the demand for redistribution should expand more the size of the public sector the less equal is the distribution of market income. One would then expect a positive relationship between government size and redistribution. This seems to be indeed the case, since the coefficient is positive and statistically significant across all specifications, irrespective of the sample and of the data source. Notice also that, when public spending to GDP is included, the value of the coefficient for the exante Gini index becomes smaller, a signal that this variable can be understood as an additional proxy for the demand of redistribution, albeit reasonably mediated by political institutions.

${ }^{13}$ We thank an anonymous referee for raising this issue. 
[Table 5 about here]

\subsubsection{Augmented model (I): supply side indicators}

In Table $6 a$ and $6 b$ we start exploring the supply side of redistribution, focusing on the role of political institutions, and examining the link between constitutional rules and redistribution according to Persson and Tabellini (2003). Given the high correlation among some of the regressors, highlighted in Table $6 c$, we present two sets of estimates, one including all the regressors at once (Table 6a), the other with some regressors included one by one (Table $6 \mathrm{~b}$ ), without interactions. First, the coefficient on the Polity 2 democracy index is always positive and significant, apart from two models using the LIS data, likely because the restricted sample of countries is characterized by a low variability with respect to this variable. The result is largely in line with the inconclusive evidence stemming from the empirical literature reviewed in Acemoglu et al. (2015). Once more, it suggests a critique to the standard Meltzer and Richard's argument: extending electoral rights to the poorer segments of the society does not need to translate into pro-poor policies. Second, the results on corruption are uncontroversial: more corruption is associated with less redistribution. Given the evidence of a high correlation between corruption and standard measures of the size of the informal economy (e.g., Buehn and Schneider, 2012), this covariate may also capture people's attitudes against redistribution, manifested by hiding a share of the tax base from the tax authorities. Third, as for the government system, presidential regimes seem to redistribute less than parliamentary systems, a result which can be explained by considering the stricter separation of powers in presidential regimes compared to parliamentary systems, which reduces the room for collusion between rent-seeking politicians (e.g., Persson and Tabellini, 2003). An alternative explanation is that the form of government affects those who, between the pro-rich and the propoor parties, will win the democratic contest over redistributive policies (Becher, 2016). Following this line of inquiry, we also find that a majoritarian voting system is associated with less redistribution, while the partisan orientation of the executive does not matter. These findings confirm the intuition of Becher (2016), whereby political institutions, more than the ideology of parties, matter in shaping redistributive policies (Le Maux et al. 2020). From a theoretical standpoint, under proportional 
representation, parties that represent different groups of citizens need to form coalitions in order to be able to implement policies; this will typically result in higher taxes and in a larger public sector (e.g., Iversen and Soskice, 2006; Alesina and Glaeser, 2004; Persson and Tabellini, 2003, Austen-Smith, 2000).

[Table $6 \mathrm{a}$ and $6 \mathrm{~b}$ about here]

In Table 7a we test the role of economic institutions, considering in particular the measures of regulation provided by the Fraser Institute (Table $7 \mathrm{~b}$ provides the correlations among these variables and the public spending to GDP ratio). According to the definitions, the measure for credit market regulation accounts for the ownership of banks, the credit to private sector and possible controls over interest rates; business regulation accounts for administrative requirements and bureaucratic costs, bribes and favouritism, licensing restrictions, cost of tax compliance; labour market regulation includes hiring and firing rules, compulsory minimum wages, centralized collective bargaining, and hours regulation. As all these measures consider freedom from regulation, one could interpret the estimated coefficients as freedom from rent-seeking behaviour, on the premise that less regulation will reduce available rents according to standard public choice arguments (Tullock, 1967). Only the coefficients for credit market regulations and business regulations turn out positive, but only the latter is also statistically significant: as one would expect, less regulation seems to be associated with more redistribution. On the contrary, the coefficient on labour market regulation is negative, albeit not statistically significant. This hints at the fact that more regulation reasonably implies a more equal wage structure and, in turn, this wage compression requires less redistribution (Barth and Moene, 2012). In this sense, redistribution is obtained ex ante by the government.

As a final remark, notice that when we control for the (political and economic) institutional differences across countries, all previous results on the role of ex-ante inequality still hold. However, public spending is now significant only in the LIS sample, suggesting that public expenditure is an equilibrium outcome of the interaction between demand and supply of redistribution.

[Table $7 \mathrm{a}$ and $7 \mathrm{~b}$ about here]

\subsubsection{Augmented model (II): instruments and resources for redistribution}


Political and economic institutions constitute the supply side of redistribution. Their interaction with demand side variables will produce equilibrium policies implemented by the government, using instruments and resources for redistributing income. Differently from economic and political institutions, which change only slowly, policies can be clearly endogenous to the level of inequality. Table 8a considers the main instruments for redistribution, looking at both the revenue and the spending side of the public budget (Table $8 \mathrm{~b}$ reports correlations between these variables and the public spending to GDP ratio). As for the revenue side, we look at the role of the personal income tax (PIT), using two variables: the top marginal tax rate and the ratio between income tax revenues and total revenues. Information on tax rates are provided by the Fraser Institute and have to be considered as 'freedom from taxation', meaning greater freedom in countries where top rates are lower. Consistently with this reading, the coefficient turns out to be negative and significant, whereas the composition of revenues does not seem to affect redistribution. Hence, it is not the PIT per se, but how the PIT treats the more affluent citizens that matters for redistribution, confirming previous suggestive evidence in, for instance, Alvaredo et al. (2013). Turning to the composition of public spending, health expenditures have a positive and significant coefficient, but only in the LIS sample; whereas public transfers, basically public pensions, are significant in the SWIID sample. As discussed in section 2 , this is largely expected, since the LIS market income already includes incomes from pensions. Interestingly, the role of the ex ante Gini coefficient, and the share of public spending out of GDP remain positive and statistically significant across almost all specifications.

[Table $8 \mathrm{a}$ and $8 \mathrm{~b}$ about here]

Table 9a looks at the resources for redistribution, while Table $9 \mathrm{~b}$ reports correlations between these variables and the public spending to GDP ratio. GDP turns out to be positive and significant, at least in the SWIID sample, meaning that richer countries (with more resources that can be redistributed) redistribute more, a result consistent with analysis in, e.g., Ravallion (2010). Results on debt and deficit are instead less clear-cut. As for debt, the coefficient is almost always negative, albeit statistically significant in just one case. On the contrary, the coefficient on deficit is significant and positive in the more complete SWIID sample. The most obvious explanation for this result is that standard Keynesian policies will help redistribution 
in the short run, but cumulating debt will require tighter fiscal policies in the long run, with a consequent negative impact on redistribution.

[Table 9 about here]

\section{Conclusions}

In this paper we have empirically examined to what extent political institutions explain different performances in income redistribution in countries that vary in terms of size of the public sector, tax systems, and governance. We use the difference between the ex ante and the ex post Gini indices of income inequality as the measure of the degree of redistribution achieved in different countries. Contrary to the simple approaches of both the 'redistribution' theory and the 'median voter' theory, our estimates provide support to the claim that political and economic institutions - i.e., the supply side of redistribution - are correlated with the degree of redistribution. In particular, our results show that, ceteris paribus, parliamentary systems and proportional electoral rules are associated with a greater degree of redistribution; corruption and regulation, on the contrary, reduce the redistribution that could be achieved. In terms of instruments for redistribution, the analysis suggests the importance of taxing the richest in the society via high tax rates on top incomes. Moreover, we find a positive and statistically significant correlation between public spending and the degree of redistribution, whereas the composition of public spending does not seem to matter at this aggregate level.

As many political institutions eventually determine the differences in the degree of redistribution across countries, our results cast a number of doubts on previous cross-country studies that analyse the relationship between redistribution, inequality, and economic efficiency. In a policy perspective, to the extent that public spending positively affects redistribution, and considering that political factors can either help (as is the case of parliamentary systems) or counteract (as is the case of corruption) the impact of spending, there are no simple policy recipes to enhance the efficiency and/or the degree of equity that are applicable in all countries. On the contrary, redistributive policies must be defined taking into account the peculiar institutions that characterize each country. A textbook example is the central tenet of market-oriented reforms to cut back welfare state spending in order to promote 
growth. In a country like Italy, where the level of corruption is perceived to be high, cutting public spending can probably increase both the amount of redistribution and economic growth. On the contrary, in a country such as Norway, virtually unaffected by corruption, the same recipe would be probably detrimental to both redistribution and growth.

Finally, one must recognize that studies on income redistribution suffer from lack of data for cross-country analysis. Given the importance of the matter, it is surprising how poor is our knowledge of the degree of redistribution achieved by different countries, and how few are the governments around the world which collect the relevant information to map this phenomenon. Additional efforts to make more information available in the future are of the outmost importance.

\section{References}

Acemoglu D., S. Naidu, P. Restrepo, J. A. Robinson (2015). Democracy, Redistribution, and Inequality. In: Handbook of Income Distribution Volume 2, 1885-1966.

Acemoglu, D., and Robinson J.A. (2015). The Rise and Decline of General Laws of Capitalism. Journal of Economic Perspectives 29 (1): 3-28.

Aidt, T., and Franck, R. (2015). Democratization Under the Threat of Revolution: Evidence from the Great Reform Act of 1832. Econometrica 83 (2): 505-547.

Alesina, A. and Giuliano, P. (2011). Preferences for redistribution. In Handbook of social economics, 93-131;

Alesina, A. and Glaeser, E. (2004). Fighting Poverty in the US and Europe: A World of Difference. Oxford: Oxford Univer.ity Press.

Allison, P. D. (2002). Quantitative Applications in the Social Sciences: Missing data. Thousand Oaks, CA: SAGE Publications, Inc.

Alvaredo F., Atkinson, A. B., Piketty, T. and Saez, E. (2013). The top 1\% in international and historical perspective. Journal of Economic Perspectives, 27(3): 3-20. 
Atkinson, A. B., Piketty, T. and Saez, E. (2011). Top Incomes in the long run of history. Journal of Economic Literature, 49(1): 3-71.

Austen-Smith, D. (2000). Redistributing income under proportional representation. Journal of Political Economy, 108 (6): 1235-1269.

Barth, E., Moene, K. O. (2012). Employment as a Price or Prize of Equality: A Descriptive Analysis. Nordic Journal of Working Life Studies, 2 (2).

Becher M. (2016). Endogenous Credible Commitment and Party Competition over Redistribution under Alternative Electoral Institutions. American Journal of Political Science, 60(3): 768-782.

Beck, T., Clarke, G:, Groff, A., Keefer, P. and Walsh, P. (2001). New tools in comparative political economy: The Database of Political Institutions. World Bank Economic Review, 15(1): 165-176.

Beck, N., and Katz, J. N (1995). What to do (and not to do) with times-series crosssection data. American Political Science Review 89: 634-647.

Besley T., Coate S. (1991). Public provision of private goods and the redistribution of income. American Economic Review, 81: 979-984.

Blais, A., Massicotte, L., and Dobrzynska, A. (2003). Why is Turnout Higher in Some Countries than in Others. Elections Canada.

Boix C. (2003). Democracy and redistribution. Cambridge University Press.

Buehn, A., Schneider, F. (2012). Corruption and the shadow economy: like oil and vinegar, like water and fire? International Tax Public Finance 19: 172-194.

Cruz, C., Keefer, P. and Scartascini, C. (2016). Database of Political Institutions Codebook, 2015 Update (DPI 2015), Inter-American Development Bank.

Danziger, S., Haveman, R. and Plotnick, R. (1981). How Income Transfer Programs Affect Work, Savings, and the Income Distribution: A Critical Review, Journal of Economic Literature 19 (3): 975-1028.

De Mello, L. and Tiongson, E. R. (2003). Income inequality and redistributive government spending. IMF Working Paper n. 14. 
Feld, L. and Schnellenbach, J. (2014). Political institutions and income (re-) distribution: evidence from developed economies. Public Choice, 159(3): 435-455.

Gottschalk, P. and Smeeding, T. M. (1997). Cross-national comparisons of earnings and income inequality. Journal of Economic Literature, 35: 663-687.

Gwartney, J., Lawson, R. and Hall, J. (2015). Economic Freedom of the World: 2015 Annual Report, Fraser Institute

Iversen, T. and Soskice, D. (2006). Electoral Institutions and the Politics of Coalitions: Why Some Democracies Redistribute More Than Others. American Political Science Review, 100: 165-181.

Larcinese, V. (2007). Voting over Redistribution and the Size of the Welfare State: The Role of Turnout. Political Studies.

Lefranc, A., Pistolesi, N. and Trannoy, A. (2008). Inequality of opportunities vs. inequality of outcomes: are Western Societies all alike? Review of Income and Wealth, 54: 513-545.

Le Maux, B., Dostálová, K. and Padovano, F. (2020), Ideology or voters? A quasiexperimental test of why left-wing governments spend more, Public Choice 182(1), 1748.

LIS (2014). Luxembourg Income Study Database [online], www.lisdatacenter.org (accessed September 2014). Luxembourg: LIS.

Mahler, V. A. and Jesuit, D. K. (2006). Fiscal redistribution in the developed countries: new insights from the Luxembourg Income Studies. Socio-Economic Review, 4: 483-511.

Marshall, M. G., Gurr, T. R. and Jaggers, K. (2016). POLITY IV PROJECT, Political Regime Characteristics and Transitions, 1800-2015, Center for Systemic Peace.

Meltzer, A. H. and Richard, S. F. (1981). A rational theory of the size of government. Journal of Political Economy, 89: 914-927.

Meltzer, A. H. and Richard, S. F. (1983). Tests of a rational theory of the size of government. Public Choice, 41: 403-418.

Milanovic, B. (2010). Four critiques of the redistribution hypothesis: An assessment. European Journal of Political Economy, 26: 147-154. 
Milanovic, B. (2000). The median-voter hypothesis, income inequality, and income redistribution: an empirical test with the required data. European Journal of Political Economy, 16: 367-410.

Musgrave, R. A. (1959). The Theory of Public Finance, New York.

Persson, T. and Tabellini, G. (2003). The economic effect of constitutions. MIT Press.

Piketty, T. and Saez, E (2013). Income Inequality in the United States, 19131998, Quarterly Journal of Economics, 118(1): 1-39

Ravallion M. (2010). Do poorer countries have less capacity for redistribution? Journal of Globalization and Development, 1(2): 1-31.

Roemer, J. E., Aaberge, R., Colombino, U., Fritzell, J., Jenkins, S. P., and Lefranc, A. (2003). To What Extent Do Fiscal Regimes Equalize Opportunities for Income Acquisition among Citizens? Journal of Public Economics, 87: 539-65.

Romer, T. (1975). Individual welfare, majority voting and the properties of a linear income tax. Journal of Public Economics, 4: 163-85.

Roth, C. and Wohlfart, J. (2018). Experienced Inequality and Preferences for Redistribution. Journal of Public Economics 167: 251-262

Salotti, S. and Trecroci, C. (2018). Cross-country evidence on the distributional impact of fiscal policy. Applied Economics, 50: 5521-5542.

Scervini, F. (2012). Empirics of the median voter: democracy, redistribution and the role of the middle class. Journal of Economic Inequality, 10(4): 529-550.

Solt, F. (2016). The Standardized World Income Inequality Database. Social Science Quarterly, 97(5): 1267-1281.

Sonedda, D. and Turati, G. (2005). Winners and losers in the Italian Welfare State. A Microsimulation Analysis of income redistribution considering in-kind transfers. Giornale degli Economisti, 64(4): 423-464.

Sturm, J.-E. and De Haan, J. (2015). Income Inequality, Capitalism, and Ethnolinguistic Fractionalization. American Economic Review, 105(5): 593-97. 
Tanninen, H. and Tuomala, M. (2001). Inherent inequality and the extent of redistribution in OECD countries. Tampere Economic Working Papers Net Series, n. 7, Department of Economics, University of Tampere.

Temple, J. (1999). The new growth evidence. Journal of Economic Literature XXXVII, 112156.

Tullock, G. (1997). Economics of income redistribution. Springer.

Tullock, G. (1967). The welfare costs of tariffs, monopolies and thefts. Western Economic Journal 5(3): 224-232

Yamamura, E. (2012) Social capital, household income, and preferences for income redistribution. European Journal of Political Economy 28: 498-511

World Bank (2013). World Development Indicator. The World Bank. 


\section{Tables and Figures}

Table 1: Descriptive statistics on Gini coefficients for the common set of country/years

\begin{tabular}{lccccccc}
\hline \hline & & \multicolumn{2}{c}{ LIS } & \multicolumn{2}{c}{ OECD } & \multicolumn{2}{c}{ SWIID } \\
& Obs. & Mean & St. dev. & Mean & St. dev. & Mean & St. err. \\
\hline Comparable sample & & & & & & & \\
\\
Gini coefficient (market income) & 33 & 38.5 & 4.18 & 45.8 & 5.18 & 46.0 & .84 \\
Gini coefficient (disposable income) & 42 & 31.2 & 3.30 & 30.2 & 3.42 & 29.6 & .60 \\
\hline \hline
\end{tabular}

Table 1b: Correlation among inequality variables

\begin{tabular}{|c|c|c|c|c|c|c|}
\hline & $\begin{array}{c}\text { Absolute } \\
\text { redistribution } \\
\text { (LIS) }\end{array}$ & $\begin{array}{c}\text { Relative } \\
\text { redistribution } \\
\text { (LIS) }\end{array}$ & $\begin{array}{c}\text { Ex-ante } \\
\text { Gini } \\
\text { (LIS) }\end{array}$ & $\begin{array}{c}\text { Mean/median } \\
\text { ratio (LIS) }\end{array}$ & $\begin{array}{l}\text { Absolute } \\
\text { red. } \\
\text { (SWIID) }\end{array}$ & $\begin{array}{c}\text { Relative } \\
\text { redistribution } \\
\text { (SWIID) }\end{array}$ \\
\hline Absolute redistribution (LIS) & 1.0000 & & & & & \\
\hline Relative redistribution (LIS) & $\begin{array}{l}0.9456 \\
134\end{array}$ & 1.0000 & & & & \\
\hline Ex-ante Gini (LIS) & $\begin{array}{l}0.1781 \\
134\end{array}$ & $\begin{array}{l}-0.0974 \\
134\end{array}$ & 1.0000 & & & \\
\hline Mean/median ratio (LIS) & $\begin{array}{l}-0.2029 \\
134\end{array}$ & $\begin{array}{l}-0.3752 \\
134\end{array}$ & $\begin{array}{l}0.8052 \\
134\end{array}$ & 1.0000 & & \\
\hline Absolute red. (SWIID) & $\begin{array}{l}0.6140 \\
(0.0065) \\
134\end{array}$ & $\begin{array}{l}0.6243 \\
(0.0048) \\
134\end{array}$ & $\begin{array}{l}-0.4065 \\
(0.0073) \\
134\end{array}$ & $\begin{array}{l}-0.2837 \\
(0.0102) \\
134\end{array}$ & 1.0000 & \\
\hline Relative redistribution (SWIID) & $\begin{array}{l}0.4782 \\
(0.0050) \\
134\end{array}$ & $\begin{array}{l}0.7306 \\
(0.0056) \\
134\end{array}$ & $\begin{array}{l}-0.5517 \\
(0.0051) \\
134\end{array}$ & $\begin{array}{l}-0.5708 \\
(0.0052) \\
134\end{array}$ & $\begin{array}{l}0.9802 \\
(0.0017) \\
2030\end{array}$ & 1.0000 \\
\hline
\end{tabular}

Correlations are estimated for variables in SWIID (standard errors in parentheses). Number of observations reported in cells. 
Table 2: Summary statistics

\begin{tabular}{|c|c|c|c|c|c|c|c|c|c|c|}
\hline \multirow[b]{2}{*}{ Variable } & \multicolumn{5}{|c|}{ LIS } & \multicolumn{5}{|c|}{ SWIID } \\
\hline & $\begin{array}{l}\text { Obs. } \\
(1)\end{array}$ & $\begin{array}{l}\text { Mean } \\
(2)\end{array}$ & $\begin{array}{l}\text { Std.Dev. } \\
\text { (3) }\end{array}$ & $\begin{array}{l}\text { Min } \\
(4)\end{array}$ & $\begin{array}{c}\operatorname{Max} \\
(5)\end{array}$ & $\begin{array}{l}\text { Obs. } \\
(6)\end{array}$ & $\begin{array}{l}\text { Mean } \\
(7)\end{array}$ & $\begin{array}{l}\text { Std.Dev. } \\
(8)\end{array}$ & $\begin{array}{c}\operatorname{Min} \\
(9)\end{array}$ & $\begin{array}{l}\text { Max } \\
(10)\end{array}$ \\
\hline Absolute red. & 84 & 8.05 & 3.04 & 2.1 & 18.1 & 1078 & $11.12^{*}$ & $.51^{*}$ & & \\
\hline $\begin{array}{l}\text { Gini coefficient (market } \\
\text { inc.) }\end{array}$ & 84 & 40.82 & 7.62 & 30.6 & 71.9 & 1078 & $46.03^{*}$ & $1.14^{*}$ & & \\
\hline $\begin{array}{l}\text { Mean/median ratio (mkt } \\
\text { income) }\end{array}$ & 84 & 1.28 & .32 & 1.06 & 3.31 & & & & & \\
\hline Public exp/GDP & 84 & 32.75 & 9.16 & 13.01 & 62.71 & 1078 & 28.85 & 11.38 & 10.01 & 134.77 \\
\hline Per capita GDP (2005 US\$) & 84 & 35580.8 & 18656.4 & 2125.7 & 87772.7 & 1078 & 19744.0 & 18618.2 & 214.7 & 87772.7 \\
\hline Debt/GDP & 60 & 45.69 & 26.26 & 4.03 & 137.87 & 628 & 48.56 & 33.10 & 1.87 & 255.21 \\
\hline Deficit/GDP & 84 & 2.20 & 5.63 & -16.65 & 32.30 & 1069 & 1.89 & 4.36 & -20.3 & 32.30 \\
\hline Polity2 democracy index & 81 & 9.80 & .53 & 8 & 10 & 1054 & 8.07 & 3.63 & -7 & 10 \\
\hline Freedom from corruption & 70 & 71.49 & 20.69 & 22 & 100 & 894 & 56.27 & 25.00 & 10 & 100 \\
\hline Parliamentary system & 84 & .76 & .43 & 0 & 1 & 1057 & .56 & .50 & 0 & 1 \\
\hline Exec. orientation: right & 78 & Ref. & & & & & & & & \\
\hline Exec. orientation: centre & 78 & .09 & .29 & 0 & 1 & 858 & .17 & .38 & 0 & 1 \\
\hline Exec. orientation: left & 78 & .41 & .49 & 0 & 1 & 858 & .43 & .49 & 0 & 1 \\
\hline $\begin{array}{l}\text { Proportional } \\
\text { representation }\end{array}$ & 84 & .82 & .39 & 0 & 1 & 1046 & .83 & .38 & 0 & 1 \\
\hline $\begin{array}{l}\text { Freedom from regulation } \\
\text { index }\end{array}$ & 66 & 7.24 & .95 & 4.53 & 8.74 & 723 & 7.02 & .90 & 3.58 & 9.13 \\
\hline $\begin{array}{l}\text { Freedom from credit } \\
\text { market regulation }\end{array}$ & 66 & 8.84 & 1.21 & 4.67 & 10 & 725 & 8.69 & 1.25 & 0 & 10 \\
\hline $\begin{array}{l}\text { Freedom from labour } \\
\text { market regulation }\end{array}$ & 66 & 6.06 & 1.66 & 2.83 & 9.26 & 706 & 6.06 & 1.41 & 2.34 & 9.46 \\
\hline $\begin{array}{l}\text { Freedom from business } \\
\text { regulation }\end{array}$ & 65 & 6.84 & 1.09 & 3.61 & 8.64 & 679 & 6.33 & 1.01 & 3.03 & 9.50 \\
\hline $\begin{array}{l}\text { (Freedom from) top } \\
\text { marginal income tax rate }\end{array}$ & 66 & 5.36 & 2.14 & 1 & 10 & 718 & 6.30 & 2.47 & 0 & 10 \\
\hline Income tax / Total revenues & 84 & 31.50 & 14.28 & 6.89 & 80.63 & 1066 & 25.65 & 13.34 & .87 & 86.12 \\
\hline $\begin{array}{l}\text { Public educ. / Total } \\
\text { expend. }\end{array}$ & 50 & 13.29 & 2.54 & 9.30 & 20.34 & 586 & 13.71 & 3.85 & 6.70 & 28.39 \\
\hline $\begin{array}{l}\text { Public educ. / Total } \\
\text { expend. } 2\end{array}$ & 66 & 17.67 & 5.34 & 9.79 & 32.96 & 779 & 17.86 & 7.35 & 1.80 & 75.38 \\
\hline $\begin{array}{l}\text { Public health expend. / } \\
\text { Total expend. }\end{array}$ & 72 & 14.30 & 3.25 & 5.17 & 19.03 & 901 & 12.92 & 4.26 & 3.07 & 30.61 \\
\hline $\begin{array}{l}\text { Public transfers / Total } \\
\text { expend. }\end{array}$ & 83 & 60.26 & 21.99 & 15.87 & 150.46 & 1029 & 50.60 & 21.93 & .23 & 167.21 \\
\hline
\end{tabular}

The sample is made by all observations for which data on redistribution and public expenditures are available.

Values marked with * are estimated, standard errors are reported in the column of the standard deviation.

Table 3: Variance decomposition of Gini coefficient, LIS

\begin{tabular}{llcccc}
\hline \hline Variable & & Mean & Std. Dev. & Min & Max \\
\hline $\begin{array}{l}\text { Gini coefficient } \\
\text { (market inc.) }\end{array}$ & overall & 40.82 & 7.62 & 30.6 & 71.9 \\
& & & & & \\
& between & & 8.93 & 32.37 & 71.2 \\
& within & & 1.43 & 36.67 & 44.34 \\
\hline Absolute red. & overall & 8.05 & 3.04 & 2.1 & 18.1 \\
& between & & 2.94 & 2.27 & 14.13 \\
& within & & 1.07 & 5.31 & 12.01 \\
\hline \hline
\end{tabular}


Table 4: Comparison across different samples and estimation methodologies

\begin{tabular}{|c|c|c|c|c|c|c|}
\hline Dep.var.: Absolute redistribution & $\begin{array}{l}\text { LIS } \\
\mathrm{b} / \mathrm{se}\end{array}$ & $\begin{array}{c}\text { SWIID } \\
\text { b/se }\end{array}$ & $\begin{array}{c}\text { SWIID } \\
\text { b/se }\end{array}$ & $\begin{array}{c}\text { OECD } \\
\text { b/se }\end{array}$ & $\begin{array}{l}\text { LIS } \\
\text { b/se }\end{array}$ & $\begin{array}{c}\text { SWIID } \\
\mathrm{b} / \mathrm{se}\end{array}$ \\
\hline Gini coeff. (market income) & $\begin{array}{c}0.690 \\
{[0.101]^{* * *}} \\
(0.053)^{* * *}\end{array}$ & $\begin{array}{c}0.806 \\
{[0.110]^{* * *}} \\
(0.054)^{* * *}\end{array}$ & $\begin{array}{c}0.439 \\
{[0.080]^{* * * *}} \\
(0.041)^{* * *}\end{array}$ & $\begin{array}{c}0.498 \\
{[0.114]^{* * *}} \\
(0.050)^{1 * * * *}\end{array}$ & $\begin{array}{c}0.267 \\
{[0.112]^{* *}} \\
(0.053)^{* * *}\end{array}$ & $\begin{array}{c}0.365 \\
{[0.128]^{* * *}} \\
(0.068)^{* * *}\end{array}$ \\
\hline Mean/median ratio (market income) & $\begin{array}{c}-25.469 \\
{[3.178]^{* * *}} \\
(2.236)^{* * *}\end{array}$ & $\begin{array}{c}-29.406 \\
{[3.304]^{* * *}} \\
(2.183)^{* * *}\end{array}$ & $\begin{array}{l}. \\
.\end{array}$ & . & $\begin{array}{l}\text {. } \\
\text {. }\end{array}$ & . \\
\hline Constant & $\begin{array}{c}34.868 \\
{[7.159]^{* * *}} \\
(5.306)^{* * *}\end{array}$ & $\begin{array}{c}45.747 \\
{[7.953]^{* * *}} \\
(5.650)^{* * *}\end{array}$ & $\begin{array}{c}-18.328 \\
{[4.912]^{* * *}} \\
(2.180)^{* * *}\end{array}$ & $\begin{array}{c}-9.781 \\
{[4.728]^{* *}} \\
(2.154)^{* * *}\end{array}$ & $\begin{array}{c}-14.725 \\
{[7.952]^{*}} \\
(4.301)^{* * *}\end{array}$ & $\begin{array}{c}-16.087 \\
{[8.718]^{*}} \\
(5.255)^{* * *}\end{array}$ \\
\hline Obs. & 134 & 134 & 2030 & 213 & 134 & 134 \\
\hline Countries & 30 & 30 & 73 & 31 & 30 & 30 \\
\hline $\mathrm{R}^{2}$ & 0.639 & $\cdot$ & . & 0.641 & 0.267 & . \\
\hline Time fixed effects & No & No & Yes & No & No & No \\
\hline Region fixed effects & Yes & Yes & Yes & Yes & Yes & Yes \\
\hline Dep.var.: Absolute redistribution & $\begin{array}{l}\text { LIS } \\
\mathrm{b} / \mathrm{se} \\
\end{array}$ & $\begin{array}{l}\text { SWIID } \\
\mathrm{b} / \mathrm{se}\end{array}$ & $\begin{array}{c}\text { SWIID } \\
\text { b/se }\end{array}$ & $\begin{array}{c}\text { OECD } \\
\text { b/se }\end{array}$ & $\begin{array}{l}\text { LIS } \\
\text { b/se }\end{array}$ & $\begin{array}{c}\text { SWIID } \\
\text { b/se }\end{array}$ \\
\hline Gini coeff. (market income) & $\begin{array}{c}0.469 \\
(0.056)^{* * *}\end{array}$ & $\begin{array}{c}0.834 \\
(0.063)^{* * *}\end{array}$ & $\begin{array}{c}0.329 \\
(0.055)^{* * *}\end{array}$ & $\begin{array}{c}0.694 \\
(0.054)^{* * *}\end{array}$ & $\begin{array}{c}0.086 \\
(0.041)^{* *}\end{array}$ & $\begin{array}{c}0.339 \\
(0.072)^{* * *}\end{array}$ \\
\hline Mean/median ratio (market income) & $\begin{array}{c}-12.194 \\
(1.445)^{* * *}\end{array}$ & $\begin{array}{c}-18.378 \\
(1.498)^{* * *}\end{array}$ & . & . & . & . \\
\hline Constant & $\begin{array}{c}4.41 \\
(1.357)^{* * *}\end{array}$ & $\begin{array}{c}0.375 \\
(2.247)\end{array}$ & $\begin{array}{l}-2.077 \\
(2.727)\end{array}$ & $\begin{array}{c}-15.317 \\
(2.519)^{* * * *}\end{array}$ & $\begin{array}{c}4.615 \\
(1.679)^{* * *}\end{array}$ & $\begin{array}{c}0.176 \\
(3.301)\end{array}$ \\
\hline Obs. & 134 & 134 & 2030 & 213 & 134 & 134 \\
\hline Countries & 30 & 30 & 73 & 31 & 30 & 30 \\
\hline $\mathrm{R}^{2}$ & 0.373 & . & . & 0.436 & 0.032 & . \\
\hline Time fixed effects & No & No & Yes & No & No & No \\
\hline Region fixed effects & No & No & No & No & No & No \\
\hline
\end{tabular}

Note: ${ }^{* * *} \mathrm{p}$-value $<.01,{ }^{* *} \mathrm{p}$-value $<0.05,{ }^{*} \mathrm{p}$-value $<.1, \wedge \mathrm{p}$-value $<.15$. Standard errors clustered at country level (in square brackets), or non-clustered (round brackets). We also compute the panel corrected standard errors, that are very similar to nonclustered standard errors. Results are available from the authors. The variable Mean/median ratio (market income) is available in LIS only and is therefore available for 134 observations. In this and all the following models, region fixed effects refer to a set of dummy variables identifying countries in Africa, Americas, Asia, Europe, Middle-East and Oceania. 
Table 5: Demand-side

\begin{tabular}{lcccccc}
\hline \hline Dep.var.: Absolute redistribution & $\begin{array}{c}\text { LIS } \\
\text { b/se }\end{array}$ & $\begin{array}{c}\text { SWIID } \\
\text { b/se }\end{array}$ & $\begin{array}{c}\text { SWIID } \\
\text { b/se }\end{array}$ & $\begin{array}{c}\text { LIS } \\
\text { b/se }\end{array}$ & $\begin{array}{c}\text { SWIID } \\
\text { b/se }\end{array}$ & $\begin{array}{c}\text { SWIID } \\
\text { b/se }\end{array}$ \\
\hline Gini coeff. (market income) & $0.536^{* * *}$ & $0.563^{* * *}$ & 0.261 & $0.353^{* * *}$ & $0.271^{* *}$ & -0.073 \\
& $(0.138)$ & $(0.095)$ & $(0.183)$ & $(0.078)$ & $(0.118)$ & $(0.156)$ \\
Mean/median ratio (market income) & $-17.125^{* * *}$ & $\cdot$ &. & $-8.481^{* * *}$ & $\cdot$ &. \\
& $(4.658)$ &. &. & $(1.715)$ &. &. \\
Public exp./GDP & $0.127^{* *}$ & 0.05 & $0.163^{* *}$ & $0.170^{* * *}$ & $0.408^{* * *}$ & $0.320^{* * *}$ \\
& $(0.053)$ & $(0.041)$ & $(0.076)$ & $(0.034)$ & $(0.104)$ & $(0.073)$ \\
Constant & $15.861^{\wedge}$ & $-28.228^{* * *}$ & -13.978 & -1.127 & $-13.186^{* *}$ & 9.876 \\
& $(10.442)$ & $(6.383)$ & $(12.070)$ & $(2.308)$ & $(5.910)$ & $(7.172)$ \\
Obs. & 84 & 1078 & 84 & 84 & 1078 & 84 \\
Countries & 25 & 63 & 25 & 25 & 63 & 25 \\
$\mathrm{R}^{2}$ & 0.653 &. &. & 0.553 &. &. \\
Time fixed effects & No & Yes & No & No & Yes & No \\
Region fixed effects & Yes & Yes & Yes & No & No & No \\
\hline \hline
\end{tabular}

Note: ${ }^{* * *} \mathrm{p}$-value $<.01,{ }^{* *} \mathrm{p}$-value $<0.05,{ }^{*} \mathrm{p}$-value $<.1,{ }^{\wedge} \mathrm{p}$-value $<.15$. Standard errors clustered at country level. 
Table 6a: Political institutions

\begin{tabular}{|c|c|c|c|c|}
\hline & $\begin{array}{l}\text { LIS } \\
\text { b/se }\end{array}$ & $\begin{array}{c}\text { SWIID } \\
\text { b/se }\end{array}$ & $\begin{array}{l}\text { LIS } \\
b / s e\end{array}$ & $\begin{array}{c}\text { SWIID } \\
\text { b/se }\end{array}$ \\
\hline Gini coeff. (market income) & $\begin{array}{c}0.526^{* * *} \\
(0.151)\end{array}$ & $\begin{array}{c}0.522^{* * *} \\
(0.104)\end{array}$ & $\begin{array}{c}0.433^{* * *} \\
(0.117)\end{array}$ & $\begin{array}{c}0.234^{* * *} \\
(0.085)\end{array}$ \\
\hline Mean/median ratio (market income) & $\begin{array}{c}-11.905 \\
(8.369)\end{array}$ & . & $\begin{array}{c}-7.589^{* * *} \\
(1.967)\end{array}$ & . \\
\hline Public exp./GDP & $\begin{array}{l}0.083^{*} \\
(0.046)\end{array}$ & $\begin{array}{c}0.001 \\
(0.027)\end{array}$ & $\begin{array}{l}0.082^{* *} \\
(0.031)\end{array}$ & $\begin{array}{c}0.136 \\
(0.094)\end{array}$ \\
\hline Polity2 democracy index & $\begin{array}{c}1.099 \\
(1.567)\end{array}$ & $\begin{array}{l}-0.258 \\
(0.282)\end{array}$ & $\begin{array}{c}1.077 \\
(1.039)\end{array}$ & $\begin{array}{l}-0.009 \\
(0.353)\end{array}$ \\
\hline Freedom from corruption & $\begin{array}{l}0.048^{*} \\
(0.028)\end{array}$ & $\begin{array}{c}0.129^{* * *} \\
(0.022)\end{array}$ & $\begin{array}{l}0.057^{* *} \\
(0.022)\end{array}$ & $\begin{array}{c}0.116^{* * *} \\
(0.035)\end{array}$ \\
\hline Presidential system & $\begin{array}{c}-1.791^{\wedge} \\
(1.172)\end{array}$ & $\begin{array}{c}0.980 \\
(2.044)\end{array}$ & $\begin{array}{c}0.884 \\
(2.016)\end{array}$ & $\begin{array}{c}-6.561^{* *} \\
(2.606)\end{array}$ \\
\hline Exec. Right & $\begin{array}{l}-0.494 \\
(1.344)\end{array}$ & $\begin{array}{c}0.196 \\
(0.718)\end{array}$ & $\begin{array}{l}-0.630 \\
(1.429)\end{array}$ & $\begin{array}{l}-1.097 \\
(0.904)\end{array}$ \\
\hline Exec. Left & $\begin{array}{l}-0.247 \\
(1.354)\end{array}$ & $\begin{array}{c}0.903 \\
(0.917)\end{array}$ & $\begin{array}{c}-0.143 \\
(1.458)\end{array}$ & $\begin{array}{c}-0.550 \\
(1.245)\end{array}$ \\
\hline Majoritarian repr. & $\begin{array}{l}-2.855^{*} \\
(1.578)\end{array}$ & $\begin{array}{c}-1.305 \\
(3.255)\end{array}$ & $\begin{array}{l}-2.508^{*} \\
(1.329)\end{array}$ & $\begin{array}{l}-1.294 \\
(4.037)\end{array}$ \\
\hline Exec. right $X$ Presidential system & $\begin{array}{c}1.212 \\
(1.683)\end{array}$ & $\begin{array}{l}-0.753 \\
(1.386)\end{array}$ & $\begin{array}{l}-1.404 \\
(2.697)\end{array}$ & $\begin{array}{c}0.060 \\
(1.429)\end{array}$ \\
\hline Exec. left $X$ Presidential system & & $\begin{array}{l}-1.955 \\
(1.718)\end{array}$ & $\begin{array}{l}-2.499 \\
(1.964)\end{array}$ & $\begin{array}{c}-0.707 \\
(1.699)\end{array}$ \\
\hline Exec. right $X$ Majoritarian repr. & $\begin{array}{l}-0.240 \\
(1.641)\end{array}$ & $\begin{array}{c}1.754 \\
(3.403)\end{array}$ & $\begin{array}{c}0.116 \\
(1.577)\end{array}$ & $\begin{array}{c}0.642 \\
(4.292)\end{array}$ \\
\hline Exec. left X Majoritarian repr. & & $\begin{array}{l}-0.923 \\
(3.346)\end{array}$ & & $\begin{array}{l}-0.333 \\
(4.103)\end{array}$ \\
\hline Constant & $\begin{array}{c}-8.529 \\
(32.941)\end{array}$ & $\begin{array}{c}-32.473^{* * *} \\
(7.833)\end{array}$ & $\begin{array}{l}-16.110 \\
(11.399)\end{array}$ & $\begin{array}{l}-7.424 \\
(5.630)\end{array}$ \\
\hline Obs. & 63 & 682 & 63 & 682 \\
\hline Countries & 23 & 53 & 23 & 53 \\
\hline $\mathrm{R}^{2}$ & 0.765 & . & 0.752 & . \\
\hline Time fixed effects & No & Yes & No & Yes \\
\hline Region fixed effects & Yes & Yes & No & No \\
\hline
\end{tabular}

Note: ${ }^{* * *} \mathrm{p}$-value $<.01,{ }^{* *} \mathrm{p}$-value $<0.05,{ }^{*} \mathrm{p}$-value $<.1,{ }^{\wedge} \mathrm{p}$-value $<.15$. Standard errors clustered at country level. 
Table 6b: Political institutions

\begin{tabular}{|c|c|c|c|c|c|c|c|c|}
\hline & $\begin{array}{l}\text { LIS } \\
\mathrm{b} / \mathrm{se}\end{array}$ & $\begin{array}{l}\text { LIS } \\
\mathrm{b} / \mathrm{se}\end{array}$ & $\begin{array}{l}\text { LIS } \\
b / s e\end{array}$ & $\begin{array}{l}\text { LIS } \\
b / s e\end{array}$ & $\begin{array}{l}\text { SWIID } \\
\text { b/se }\end{array}$ & $\begin{array}{l}\text { SWIID } \\
\mathrm{b} / \mathrm{se}\end{array}$ & $\begin{array}{l}\text { SWIID } \\
\text { b/se }\end{array}$ & $\begin{array}{l}\text { SWIID } \\
\text { b/se }\end{array}$ \\
\hline Gini coeff. (market income) & $\begin{array}{l}0.343^{* * *} \\
(0.092)\end{array}$ & $\begin{array}{l}0.411^{* * *} \\
(0.090)\end{array}$ & $\begin{array}{l}0.499^{* * *} \\
(0.104)\end{array}$ & $\begin{array}{l}0.339^{* * *} \\
(0.089)\end{array}$ & $\begin{array}{l}0.179^{\wedge} \\
(0.110)\end{array}$ & $\begin{array}{l}0.239^{* * *} \\
(0.085)\end{array}$ & $\begin{array}{l}0.162 \\
(0.125)\end{array}$ & $\begin{array}{l}0.071 \\
(0.120)\end{array}$ \\
\hline Mean/median ratio (market income) & $\begin{array}{l}-6.935^{* * *} \\
(1.567)\end{array}$ & $\begin{array}{l}-7.885^{* * *} \\
(1.578)\end{array}$ & $\begin{array}{l}-9.932^{* * *} \\
(1.814)\end{array}$ & $\begin{array}{l}-7.244^{* * *} \\
(1.680)\end{array}$ & . & . & . & . \\
\hline Public exp./GDP & $\begin{array}{l}0.155^{* * *} \\
(0.036)\end{array}$ & $\begin{array}{l}0.125^{* * *} \\
(0.038)\end{array}$ & $\begin{array}{l}0.125^{* * *} \\
(0.034)\end{array}$ & $\begin{array}{l}0.129^{* * *} \\
(0.038)\end{array}$ & $\begin{array}{l}0.251^{* *} \\
(0.101)\end{array}$ & $\begin{array}{l}0.226^{* *} \\
(0.098)\end{array}$ & $\begin{array}{l}0.340^{* * *} \\
(0.105)\end{array}$ & $\begin{array}{l}0.328^{* * *} \\
(0.118)\end{array}$ \\
\hline Polity2 democracy index & $\begin{array}{l}0.407 \\
(0.847)\end{array}$ & $\begin{array}{l}0.831 \\
(0.600)\end{array}$ & $\begin{array}{l}2.063^{* *} \\
(0.847)\end{array}$ & $\begin{array}{l}1.578^{* *} \\
(0.635)\end{array}$ & $\begin{array}{l}0.368^{*} \\
(0.198)\end{array}$ & $\begin{array}{l}0.371^{* *} \\
(0.167)\end{array}$ & $\begin{array}{l}0.749^{* * *} \\
(0.243)\end{array}$ & $\begin{array}{l}1.044^{* *} \\
(0.406)\end{array}$ \\
\hline Freedom from corruption & $\begin{array}{l}0.051^{* *} \\
(0.022)\end{array}$ & . & . & . & $\begin{array}{l}0.135^{* * *} \\
(0.028)\end{array}$ & . & . & . \\
\hline Presidential system & . & $\begin{array}{l}-2.122^{* *} \\
(0.937)\end{array}$ & . & . & . & $\begin{array}{l}-7.289^{* * *} \\
(1.777)\end{array}$ & . & . \\
\hline Majoritarian repr. & . & . & $\begin{array}{l}-2.138^{* *} \\
(0.974)\end{array}$ & . & . & . & $\begin{array}{l}1.523 \\
(1.526)\end{array}$ & . \\
\hline Exec. Right & . & . & . & $\begin{array}{l}-1.288 \\
(1.237)\end{array}$ & . & . & . & $\begin{array}{l}-0.928 \\
(1.413)\end{array}$ \\
\hline Exec. Left & . & . & . & $\begin{array}{l}-0.146 \\
(0.478)\end{array}$ & . & . & . & $\begin{array}{l}-0.236 \\
(0.850)\end{array}$ \\
\hline Constant & $\begin{array}{l}-9.703 \\
(8.398)\end{array}$ & $\begin{array}{l}-10.415 \\
(7.032)\end{array}$ & $\begin{array}{l}-23.593^{* *} \\
(9.608)\end{array}$ & $\begin{array}{l}-14.893^{* *} \\
(7.058)\end{array}$ & $\begin{array}{l}-16.483^{* * *} \\
(5.233)\end{array}$ & $\begin{array}{l}-7.1 \\
(4.895)\end{array}$ & $\begin{array}{l}-12.957^{* *} \\
(5.428)\end{array}$ & $\begin{array}{l}-9.951^{*} \\
(5.469)\end{array}$ \\
\hline Obs & 67 & 81 & 81 & 76 & 870 & 1042 & 1031 & 846 \\
\hline Countries & 24 & 24 & 24 & 23 & 61 & 61 & 61 & 55 \\
\hline $\mathrm{R}^{2}$ & 0.665 & 0.638 & 0.629 & 0.551 & . & . & . & . \\
\hline
\end{tabular}

Table 6c: correlation among regressors

\begin{tabular}{|c|c|c|c|c|c|c|}
\hline & $\begin{array}{c}\text { Public } \\
\text { exp./GDP }\end{array}$ & $\begin{array}{c}\text { Polity2 } \\
\text { democracy } \\
\text { index }\end{array}$ & $\begin{array}{c}\text { Freedom from } \\
\text { corruption }\end{array}$ & $\begin{array}{c}\text { Presidential } \\
\text { system }\end{array}$ & $\begin{array}{c}\text { Executive } \\
\text { orientation }\end{array}$ & $\begin{array}{c}\text { Majoritarian } \\
\text { repr. }\end{array}$ \\
\hline Public exp./GDP & $\begin{array}{c}1.0000 \\
1078\end{array}$ & & & & & \\
\hline Polity2 & 0.3506 & 1.0000 & & & & \\
\hline democracy index & 1054 & 1922 & & & & \\
\hline Freedom from & 0.3330 & 0.4441 & 1.0000 & & & \\
\hline corruption & 894 & 1171 & 1238 & & & \\
\hline Presidential & 0.4452 & 0.4395 & 0.6400 & 1.0000 & & \\
\hline system & 1057 & 1898 & 1180 & 1933 & & \\
\hline Executive & -0.0355 & -0.0738 & -0.0685 & 0.0122 & 1.0000 & \\
\hline orientation & 858 & 1569 & 936 & 1601 & 1601 & \\
\hline Majoritarian & 0.2102 & 0.3682 & -0.0169 & 0.0159 & -0.0837 & 1.0000 \\
\hline repr. & 1046 & 1805 & 1135 & 1824 & 1518 & 1824 \\
\hline
\end{tabular}


Table 7a: Rent seeking

\begin{tabular}{lcccc}
\hline \hline & $\begin{array}{c}\text { LIS } \\
\mathrm{b} / \mathrm{se}\end{array}$ & $\begin{array}{c}\text { SWIID } \\
\mathrm{b} / \mathrm{se}\end{array}$ & $\begin{array}{c}\text { LIS } \\
\mathrm{b} / \mathrm{se}\end{array}$ & $\begin{array}{c}\text { SWIID } \\
\mathrm{b} / \mathrm{se}\end{array}$ \\
\hline Gini coeff. (market income) & $0.534^{* * *}$ & $0.516^{* * *}$ & $0.394^{* * *}$ & $0.281^{* *}$ \\
& $(0.153)$ & $(0.098)$ & $(0.086)$ & $(0.130)$ \\
Mean/median ratio (market income) & $-13.940^{* *}$ & $\cdot$ & $-8.508^{* * *}$ & $\cdot$ \\
& $(5.834)$ & $\cdot$ & $(1.547)$ &. \\
Public exp./GDP & $0.128^{* *}$ & $0.059^{\wedge}$ & $0.164^{* * *}$ & $0.422^{* * *}$ \\
& $(0.055)$ & $(0.039)$ & $(0.044)$ & $(0.083)$ \\
Freedom from credit market regulation & 0.125 & 0.117 & 0.27 & 0.677 \\
& $(0.293)$ & $(0.305)$ & $(0.286)$ & $(0.475)$ \\
Freedom from labour market regulation & -0.21 & -0.047 & -0.205 & -0.136 \\
& $(0.221)$ & $(0.437)$ & $(0.208)$ & $(0.499)$ \\
Freedom from business regulation & 0.62 & $1.325^{* * *}$ & $0.862^{* *}$ & $1.995^{* * *}$ \\
& $(0.426)$ & $(0.474)$ & $(0.339)$ & $(0.740)$ \\
Constant & & & & - \\
& 2.142 & $-34.325^{* * *}$ & $-9.517^{*}$ & $30.669^{* * *}$ \\
Obs. & $(16.595)$ & $(8.435)$ & $(4.757)$ & $(7.833)$ \\
Countries & 65 & 679 & 65 & 679 \\
$\mathrm{R}^{2}$ & 24 & 60 & 24 & 60 \\
Time fixed effects & 0.695 &. & 0.649 &. \\
Region fixed effects & No & Yes & No & Yes \\
\hline \hline
\end{tabular}

Note: ${ }^{* * *} \mathrm{p}$-value $<.01,{ }^{* *} \mathrm{p}$-value $<0.05,{ }^{*} \mathrm{p}$-value $<.1,{ }^{\wedge} \mathrm{p}$-value $<.15$. Standard errors clustered at country level.

Table $7 \mathrm{~b}$ : correlation among regressors

\begin{tabular}{ccccc}
\hline \hline & Public exp./GDP & $\begin{array}{c}\text { Freedom from credit } \\
\text { market regulation }\end{array}$ & $\begin{array}{c}\text { Freedom from labour } \\
\text { market regulation }\end{array}$ & $\begin{array}{c}\text { Freedom from } \\
\text { business regulation }\end{array}$ \\
\hline Public exp./GDP & 1.0000 & & & \\
Freedom from credit & 1078 & & & \\
market regulation & -0.0061 & 1.0000 & 1.0000 & 1.0000 \\
Freedom from labour & 725 & 1052 & 985 & 892 \\
market regulation & -0.1045 & 0.3107 & 0.3695 & 891 \\
Freedom from & 706 & 985 & & \\
business regulation & 0.1128 & 0.4169 & & \\
\hline \hline
\end{tabular}


Table 8a: Instruments for redistribution

\begin{tabular}{lcccc}
\hline \hline & $\begin{array}{c}\text { LIS } \\
\mathrm{b} / \mathrm{se}\end{array}$ & $\begin{array}{c}\text { SWIID } \\
\mathrm{b} / \mathrm{se}\end{array}$ & $\begin{array}{c}\text { LIS } \\
\mathrm{b} / \mathrm{se}\end{array}$ & $\begin{array}{c}\text { SWIID } \\
\mathrm{b} / \mathrm{se}\end{array}$ \\
\hline Gini coeff. (market income) & $0.342^{*}$ & $0.565^{* * *}$ & $0.319^{* *}$ & $0.298^{* *}$ \\
& $(0.169)$ & $(0.101)$ & $(0.112)$ & $(0.147)$ \\
Mean/median ratio (market income) & -3.972 & $\cdot$ & $-6.800^{* * *}$ & $\cdot$ \\
& $(6.004)$ & $\cdot$ & $(1.734)$ &. \\
Public exp./GDP & $0.180^{* *}$ & 0.046 & $0.176^{* * *}$ & $0.270^{* *}$ \\
& $(0.068)$ & $(0.042)$ & $(0.055)$ & $(0.102)$ \\
(Freedom from) top marginal income tax rate & $-0.460^{* *}$ & $-0.614^{* * *}$ & $-0.536^{* * *}$ & $-1.154^{* * *}$ \\
& $(0.208)$ & $(0.271)$ & $(0.170)$ & $(0.355)$ \\
Income tax / Total revenues & -0.005 & 0.002 & -0.021 & -0.058 \\
& $(0.046)$ & $(0.053)$ & $(0.032)$ & $(0.052)$ \\
Public education expend. / Total expend. & 0.068 & 0.049 & 0.012 & 0.094 \\
& $(0.092)$ & $(0.053)$ & $(0.086)$ & $(0.069)$ \\
Public health expend. / Total expend. & 0.226 & 0.122 & $0.280^{* *}$ & 0.135 \\
& $(0.168)$ & $(0.104)$ & $(0.122)$ & $(0.125)$ \\
Public transfers / Total expend. & 0.01 & 0.03 & 0.01 & $0.101^{* * *}$ \\
& $(0.011)$ & $(0.022)$ & $(0.011)$ & $(0.028)$ \\
Constant & -15.232 & $-29.733^{* * *}$ & -3.21 & -10.275 \\
& $(18.827)$ & $(8.484)$ & $(6.100)$ & $(8.267)$ \\
Obs. & 51 & 518 & 51 & 518 \\
Countries & 19 & 54 & 19 & 54 \\
$\mathrm{R}^{2}$ & 0.746 & $\cdot$ & 0.721 & $\cdot$ \\
Time fixed effects & No & Yes & No & Yes \\
Region fixed effects & Yes & Yes & No & No \\
\hline \hline
\end{tabular}

Note: ${ }^{* * *}$ p-value $<.01,{ }^{* *} \mathrm{p}$-value $<0.05,{ }^{*} \mathrm{p}$-value $<.1$. Standard errors clustered at country level.

Table 8b: correlation among regressors

\begin{tabular}{|c|c|c|c|c|c|c|}
\hline & $\begin{array}{c}\text { Public } \\
\text { exp./GDP }\end{array}$ & $\begin{array}{l}\text { (Freedom } \\
\text { from) top } \\
\text { marginal } \\
\text { income tax } \\
\text { rate }\end{array}$ & $\begin{array}{c}\text { Income tax / } \\
\text { Total } \\
\text { revenues }\end{array}$ & $\begin{array}{c}\text { Public } \\
\text { education } \\
\text { expend. / } \\
\text { Total expend. }\end{array}$ & $\begin{array}{l}\text { Public health } \\
\text { expend./ } \\
\text { Total expend. }\end{array}$ & $\begin{array}{c}\text { Public } \\
\text { transfers / } \\
\text { Total expend. }\end{array}$ \\
\hline Public exp./GDP & $\begin{array}{c}1.0000 \\
1078\end{array}$ & & & & & \\
\hline (Freedom from) top & -0.4923 & 1.0000 & & & & \\
\hline $\begin{array}{l}\text { marginal income } \\
\text { tax rate }\end{array}$ & 718 & 1039 & & & & \\
\hline $\begin{array}{l}\text { Income tax / Total } \\
\text { revenues }\end{array}$ & $\begin{array}{c}-0.0396 \\
1066\end{array}$ & $\begin{array}{c}-0.2997 \\
749\end{array}$ & $\begin{array}{c}1.0000 \\
1146\end{array}$ & & & \\
\hline Public education & -0.5029 & 0.1963 & 0.1517 & 1.0000 & & \\
\hline $\begin{array}{l}\text { expend. / Total } \\
\text { expend. }\end{array}$ & 779 & 555 & 771 & 779 & & \\
\hline Public health & 0.1353 & -0.1396 & 0.2030 & 0.0903 & 1.0000 & \\
\hline $\begin{array}{l}\text { expend. / Total } \\
\text { expend. }\end{array}$ & 901 & 851 & 952 & 665 & 1203 & \\
\hline Public transfers / & 0.2194 & -0.2154 & 0.0459 & -0.0533 & 0.1321 & 1.0000 \\
\hline Total expend. & 1029 & 723 & 1074 & 747 & 909 & 1079 \\
\hline
\end{tabular}


Table 9a: Resources for redistribution

\begin{tabular}{lcccc}
\hline \hline Dep.var.: Absolute redistribution & $\begin{array}{c}\text { LIS } \\
\mathrm{b} / \mathrm{se}\end{array}$ & $\begin{array}{c}\text { SWIID } \\
\mathrm{b} / \mathrm{se}\end{array}$ & $\begin{array}{c}\text { LIS } \\
\mathrm{b} / \mathrm{se}\end{array}$ & $\begin{array}{c}\text { SWIID } \\
\mathrm{b} / \mathrm{se}\end{array}$ \\
\hline Gini coeff. (market income) & $0.465^{* * *}$ & $0.574^{* * *}$ & $0.426^{* * *}$ & $0.347^{* * *}$ \\
& $(0.123)$ & $(0.078)$ & $(0.077)$ & $(0.097)$ \\
Mean/median ratio (market income) & $-10.162^{*}$ & $\cdot$ & $-7.878^{* * *}$ &. \\
& $(5.134)$ &. & $(1.223)$ &. \\
Public exp./GDP & $0.125^{*}$ & 0.039 & $0.158^{* * *}$ & $0.270^{* * *}$ \\
& $(0.063)$ & $(0.050)$ & $(0.037)$ & $(0.092)$ \\
GDP (2005 US\$) & 0 & $0.000^{* * *}$ & 0 & $0.000^{* * *}$ \\
& $(0.000)$ & $(0.000)$ & $(0.000)$ & $(0.000)$ \\
Debt/GDP & -0.004 & 0.001 & -0.002 & $-0.044^{* *}$ \\
& $(0.016)$ & $(0.013)$ & $(0.012)$ & $(0.021)$ \\
Deficit/GDP & 0.03 & 0.084 & 0 & $0.235^{*}$ \\
& $(0.068)$ & $(0.068)$ & $(0.046)$ & $(0.117)$ \\
Constant & 0.674 & $-31.718^{* * *}$ & $-5.330^{*}$ & $-13.693^{* * *}$ \\
& $(12.673)$ & $(5.295)$ & $(2.809)$ & $(4.785)$ \\
Obs. & 60 & 624 & 60 & 624 \\
Countries & 20 & 55 & 20 & 55 \\
r2 & 0.702 &. & 0.683 &. \\
Time fixed effects & No & Yes & No & Yes \\
Region fixed effects & Yes & Yes & No & No \\
\hline \hline
\end{tabular}

Note: ${ }^{* * *} \mathrm{p}$-value $<.01,{ }^{* *} \mathrm{p}$-value $<0.05,{ }^{*} \mathrm{p}$-value $<.1,{ }^{\wedge} \mathrm{p}$-value $<.15$. Standard errors clustered at country level.

Table 9b: correlation among regressors

\begin{tabular}{|c|c|c|c|c|}
\hline & $\begin{array}{l}\text { Public exp./GDP } \\
\end{array}$ & "GDP (2005 US\$) & $\begin{array}{l}\text { Debt/GDP } \\
\end{array}$ & $\begin{array}{l}\text { Deficit/GDP } \\
\end{array}$ \\
\hline Public exp./GDP & $\begin{array}{c}1.0000 \\
1078\end{array}$ & & & \\
\hline GDP (2005 US\$) & $\begin{array}{c}0.3527 \\
1078\end{array}$ & $\begin{array}{c}1.0000 \\
1923\end{array}$ & & \\
\hline Debt/GDP & $\begin{array}{c}0.3408 \\
628\end{array}$ & $\begin{array}{c}-0.0208 \\
684\end{array}$ & $\begin{array}{c}1.0000 \\
684\end{array}$ & \\
\hline Deficit/GDP & $\begin{array}{c}0.3063 \\
1069\end{array}$ & $\begin{array}{c}-0.1459 \\
1115\end{array}$ & $\begin{array}{c}0.2083 \\
653\end{array}$ & $\begin{array}{c}1.0000 \\
1115\end{array}$ \\
\hline
\end{tabular}


Figure 1: Comparison between different data sources of Gini coefficients for the common set of country/years

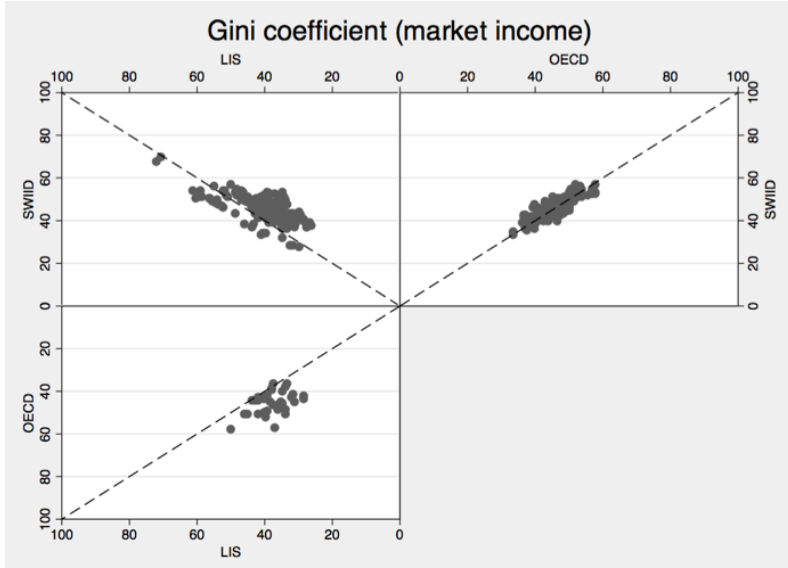

Correlation coefficients: LIS-SWIID: 0.66 (218 obs), OECD-SWIID: 0.85 (208 obs), OECD-LIS: 0.40 (40 obs)

Figure 2: Comparison between different data sources of Gini coefficients for the common set of country/years

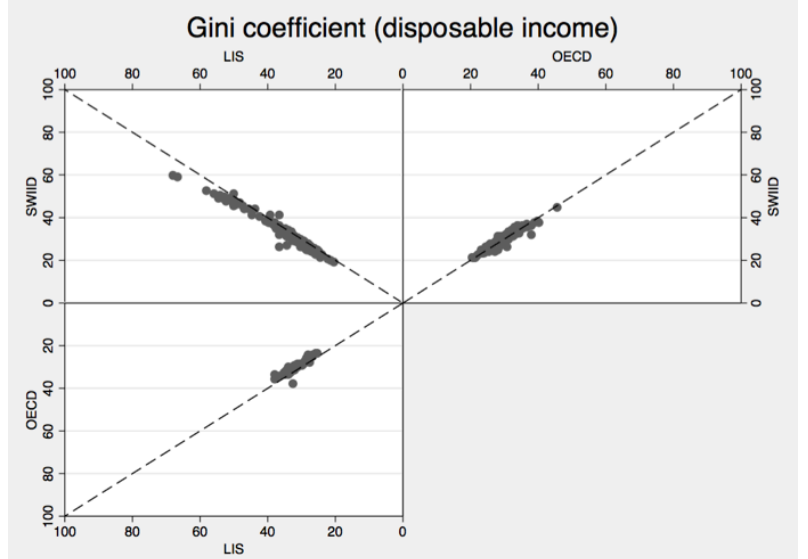

Correlation coefficients: LIS-SWIID: 0.98 (224 obs), OECD-SWIID: 0.96 (216 obs), OECD-LIS: 0.91 (42 obs) 
Table A1: Sample

\begin{tabular}{|c|c|c|c|c|c|}
\hline Country & SWIID & LIS & Country & SWIID & LIS \\
\hline Argentina & Yes & No & Latvia & Yes & No \\
\hline Armenia & Yes & No & Lithuania & Yes & No \\
\hline Australia & Yes & Yes & Luxembourg & Yes & Yes \\
\hline Austria & Yes & Yes & Mexico & Yes & No \\
\hline Azerbaijan & Yes & No & Moldova & Yes & No \\
\hline Belarus & Yes & No & Netherlands & Yes & Yes \\
\hline Belgium & Yes & Yes & New Zealand & Yes & No \\
\hline Brazil & Yes & Yes & Norway & Yes & Yes \\
\hline Bulgaria & Yes & No & Panama & Yes & No \\
\hline Canada & Yes & Yes & Paraguay & Yes & No \\
\hline Chile & Yes & No & Philippines & Yes & No \\
\hline China & Yes & No & Poland & Yes & Yes \\
\hline Colombia & Yes & Yes & Portugal & Yes & No \\
\hline Costa Rica & Yes & No & Romania & Yes & Yes \\
\hline Czech Republic & Yes & Yes & Russia & Yes & No \\
\hline Denmark & Yes & Yes & Singapore & Yes & No \\
\hline Dominican Republic & Yes & No & Slovak Republic & Yes & Yes \\
\hline El Salvador & Yes & No & Slovenia & Yes & No \\
\hline Estonia & Yes & Yes & South Africa & Yes & Yes \\
\hline Finland & Yes & No & South Korea & Yes & Yes \\
\hline France & Yes & No & Spain & Yes & Yes \\
\hline Georgia & Yes & No & Sri Lanka & Yes & No \\
\hline Germany & Yes & Yes & Sweden & Yes & Yes \\
\hline Greece & Yes & Yes & Switzerland & Yes & Yes \\
\hline Guatemala & Yes & Yes & Taiwan & Yes & Yes \\
\hline Honduras & Yes & No & Tajikistan & Yes & No \\
\hline Hong Kong & Yes & No & Thailand & Yes & No \\
\hline Hungary & Yes & No & Turkmenistan & Yes & No \\
\hline Iceland & Yes & Yes & Ukraine & Yes & No \\
\hline India & Yes & No & United Kingdom & Yes & Yes \\
\hline Ireland & Yes & Yes & United States & Yes & Yes \\
\hline Israel & Yes & Yes & Uruguay & Yes & No \\
\hline Italy & Yes & No & Uzbekistan & Yes & No \\
\hline Japan & Yes & Yes & Venezuela & Yes & No \\
\hline Kazakhstan & Yes & No & Vietnam & Yes & No \\
\hline Kenya & Yes & No & Yugoslavia/Serbia & Yes & No \\
\hline Kyrgyz Republic & Yes & No & & & \\
\hline
\end{tabular}

Countries for which it is possible to compute a redistribution measure, by dataset. Notice that countries for which only one between ex-ante and ex-post redistribution is available are not reported in the table. 